\title{
ACRL issues for the 80s
}

\section{ACRL's two presidential candidates offer their views on}

\section{the Association's future.}

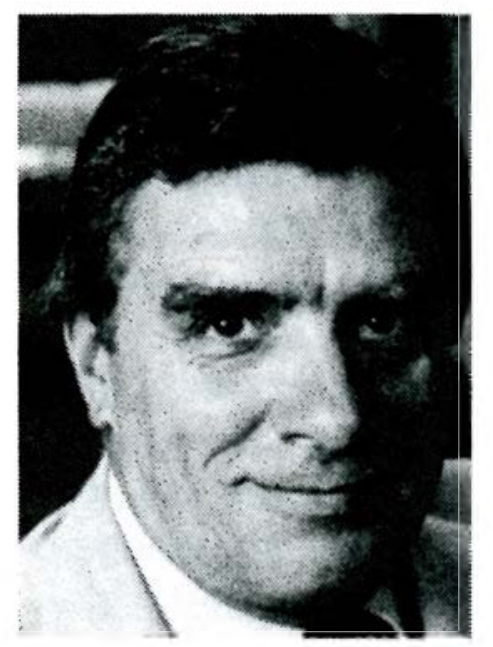

Joseph A. Boissé

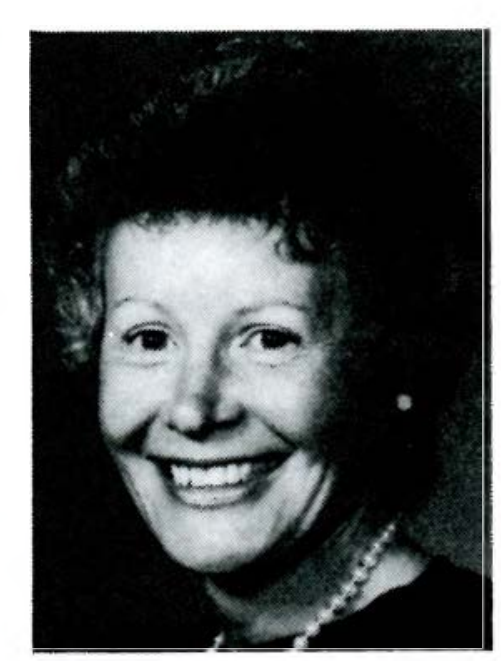

Joan Chambers
$\mathbf{T}$ his presentation of statements from ACRL's candidates for Vice-President/President-Elect is an information service for ACRL members. Many of the issues and concerns facing ACRL are discussed informally at meetings, but this does not provide a national forum available to all members. These statements provide the basis for an informed choice when you receive your ballot next month.

\section{Joseph A. Boissé:}

In the past several years ACRL has been fortunate to have as President a succession of extremely. competent and tirelessly energetic individuals. The Association is financially strong, enjoys solid support from its membership and has given serious attention to providing services to and programs for the membership.

At the 1986 annual conference in New York, the Strategic Planning Task Force presented to the ACRL Board its recommended Strategic Plan for ACRL. That document received Board approval on July 1,1986 , and is now in place. The document represents much hard work by many individuals. It also is based on a great deal of grass roots consul- tation. It is, in a very real sense, where the membership of this Association wants the organization to go.

It is not an insignificant document and implementing it over the next five years will require dedication, energy, and persistence. I believe that the most important commitment I can make as candidate for Vice-President/President-Elect of ACRL is to devote whatever time and effort is necessary to insure that the Strategic Plan does not remain just a plan. I will work with the membership, the appropriate Committees, the Board and the ACRL staff to move it from a blueprint for action to reality.

During the past couple of months I have written to more than two hundred colleagues in ACRL seeking to know about their professional concerns and about their vision for ACRL. I have received several dozen replies either by mail or by telephone. There is virtual unanimous support for the plan and this is precisely because it is seen as addressing member hopes and concerns.

Let me simply comment on and emphasize a few topics which grew out of those consultations and which are of special interest to me:

1. The role of ACRL within ALA. I have always advocated a strong ACRL within a strong ALA. The relationship between the two groups has been stormy at times and it probably will be so again in the future. On the whole, however, the relationship has been synergistic. If elected, my position will be to pursue a position of aggressive interdependance within ALA. It is true that the parent organization supports the division in many ways. But it is equally true that the division contributes enormously to ALA. We must work to insure that the relationship remains equitable and that ALA continues to take into consideration the interests and concerns of ACRL members as association policy is developed. 
2. The ACRL structure. There are more than a dozen sections within ACRL. They run the gamut from very large groups to very small groups. We must recognize that simply because of the nature of our profession, legitimate areas of interest will not always attract large numbers of individuals. The Association must be willing to support groups which it judges to be of value but which may find it difficult to support themselves. We must continue to strive to meet the professional needs of all of our members.

3. Equity and recruitment. ACRL must continue to work for equity both within our profession and within the greater society in which we operate. Furthermore, we must devote some of our resources to the task of recruitment. A recent survey of college freshmen concerning their future professional plans concluded that $0 \%$ were interested in librarianship. That is intolerable. We must develop a strategy for recruiting generally and especially for actively recruiting underrepresented minorities to the ranks of academic and research librarianship.

4. Continuing education. In my own poll of colleagues this surfaced as the most frequently mentioned concern. ACRL has already done much in this area and has been working with its chapters to establish an effective delivery network. That partnership-ACRL and its chapters-must continue and must be enhanced however possible. The chapters enable us to reach out easily to the grassroots level in this area; we must therefore strengthen the cooperative effort and expand it to the extent possible.

5. Access to information. This last item encompasses a variety of issues all of which will affect, in one way or another, how our patrons will find the information they need. We must be constantly vigilant to insure that new technologies are not used to limit access to information but rather to enhance it. We must not be hesitant to reproach the private sector for putting unnecessary and unjustifiable barriers between individuals and the information they need for their work. And we must take pride in our role of conservators and transmitters of our culture.

I would consider it an honor to serve this organization as its Vice-President and then as its President.

\section{Joan Chambers:}

If elected president of ACRL, I would assume office right in the middle of the timeline for implementing the Strategic Plan that was approved by the ACRL Board on July 1, 1986. The genesis of this plan was the recognition that to continue as a dynamic and financially sound organization, ACRL needed a structured planning process. The basis of the plan was the Activity Model for the 1990s, which was developed by an ACRL committee appointed in 1980. Beginning with their state- ment of mission, goals and objectives, and building on the 1984-85 membership survey and the 1985 President's Program, the ACRL Strategic Planning Task Force developed the Strategic Plan.

As the largest ALA division and as an organization representing diverse interests, ACRL not only needs the sense of purpose and direction provided by a systematic planning process, but also the sense of unity and continuity such a process can bring to an organization of ever-changing officers. The Strategic Plan and its implementation merit the commitment, support and active involvement of all members and officers of ACRL. In addition, the officers will need to identify a way to evaluate the effectiveness of the Strategic Plan in achieving ACRL's goals and carrying out its mission. I am especially committed to the plan because I believe that it is directly responsive to the five priorities determined by the membership: strengthen and broaden the publications program; expand continuing education and professional development opportunities; provide and promote standards, guidelines and information about accreditation; serve as liaison for members and their libraries to the rest of the higher education community; and support ACRL Chapter activities.

Along with the plan, there are other activities and programs which are already established and ongoing that I believe merit continuation and advancement, such as the annual awards that recognize and honor members of the Association. Both the systematic planning process and the ongoing activities need to be continuously infused with fresh ideas. As an officer, I would encourage innovation and ensure opportunities for creative thinking in order to retain the Association's vitality and responsiveness.

My third area of focus would be to work, as a member of the Board, with the elected and appointed officers and members of the sub-units of ACRL-182 committees, 13 sections, task forces, ad hoc committees, and discussion groups. I believe that the actions of the Board should facilitate those activities that reflect the goals and objectives of ACRL.

In addition to working with the Board and other appointed and elected officers, as president, I would support the efforts of the ACRL staff and assist with their development of an annual operating plan to implement the Strategic Plan.

I believe it is in the best interests of ACRL to work collaboratively with ALA and to form alliances with the other divisions to address issues of mutual concern and to achieve shared goals. As president, I would promote cooperation and seek to identify mutual interests and shared goals. The ACRL initiative in the administration of the Divisional Leadership Enhancement Program, funded by the J. Morris Jones Award, is an example of a program which has encouraged cooperaticn and understanding among the divisions and ALA.

Over the past few years, I have observed the in- 
creased activity on the part of ACRL presidents in attending Chapter meetings and participating in programs to attract new members. The effort to recruit new members and to retain current members is an ongoing effort best shared by all of us who believe that membership in ACRL mutually benefits the individual, the Association, and the profession.

I have observed, as well, the expanding role of the President in serving as an advocate and in representing the Association in the higher education community. I am committed to enhancing the awareness of those concerned with higher education and to increasing their understanding of the role of librarians as full partners in the academic enterprise.

I believe that the Association has benefited from competent leaders and members who have volunteered their time and effort to shape the Association and to influence its future direction. In addition, the Association has been fortunate to attract an exceptional staff and Executive Director. As president, I would endeavor to maintain a balance between continuity and change while focusing on the seven areas identified above. I would endeavor, as well, to carry on the tradition of thoughtful and responsible decision-making and fiscally sound budgeting established by my predecessors. Finally, in return, I would enjoy the pleasure of many new acquaintances, the satisfaction of our shared achievements, and the benefit of our mutual growth and development.

Editor's Note: Joseph A. Boissé is university librarian at the University of California, Santa Barbara. Joan Chambers is director of libraries at Colorado State University, Fort Collins.

\section{The Martinus Nijhoff Study Grant}

In 1986 Frederick C. Lynden, assistant university librarian for technical services, Brown University, was the first recipient of the Martinus Nijhoff International West European Specialist Study Grant. In September 1986 Lynden traveled to the Netherlands, France, and West Germany to pursue his project on gathering data on the prices of European library materials and encouraging the production of European academic book and serial price indexes. The project included visits to vendors, bookselling associations, and librarians to study how price data from Europe is collected and disseminated.

The study trip lasted two weeks, and consisted of interviews of selected dealers, university librarians, collection managers, and book trade association officials. In addition to interviewing these individuals, Lynden collected samples of price data, price studies, and collection budgets. His complete study will be finished in early March, but he has reported some tentative conclusions which follow:

- Although there is general data available from publishing/bookselling associations available in France, Germany, and the Netherlands, vendors are really the best source of information on foreign price trends for "academic" titles.

-Actual inflation rates for foreign titles are not as high as exchange rates. It is the declining value of the dollar which is imperiling budgets. Librarians should therefore spend time tracking currency changes which are heavily affecting the costs of foreign titles.

- One promising way of dealing with the currency changes is to take advantage of prepayment plans offered by vendors on their serial lists.

- As studies by librarians in France, Germany, and the Netherlands proved, local cost studies are an effective means of calculating the cost rise on foreign titles supplied to institutions.

- There are sources of data on price trends of foreign materials which can be used for comparison purposes: France, Livres Hebdo; Germany, Buch und Buchhandel in Zahlen; and the Netherlands, Stichting Speurwerk's BoekenTitelproduktie.

- The International Publishing Association is concerned enough about the price increases that it has polled libraries about the effects of high priced serials on the purchasing of monographs.

- In addition to being able to produce general data on the prices of monographs supplied on blanket orders, some vendors can now supply data which is institution-specific. Those vendors which cannot do so are now seeking to provide such a service.

- All of the parties visited were informed about the existence of a new draft international standard for price indexes for library materials. In one case, that of the German national price study for books where standard UNESCO subject headings are already used for reporting prices and booksellers wish to use a very simplified subject scheme, the standard will provide justification for the continued use of the UNESCO subject system.

- A promising method to price trends more accurately is to record an average price per page. This methodology is used by the German annual, Buch und Buchhandel in Zahlen (Bogen Preisen) and may be useful in other studies as a measure of price changes.

- Vendors and publishing/bookselling association officials, aware of the British and German discriminatory price practices, were uniformly upset about this "restraint" of trade and will be working 
actively to discourage these practices.

- Those organizations with computer records are best able to track price changes in library materials and provide information to customers or users. It is essential to provide such information to libraries for use in their budget justification and planning for collection development.

- As European vendors and libraries automate their processes, they need to be made aware of the requirements of North American libraries for library materials price data.

The first Nijhoff Study Grant provided an opportunity for Lynden to follow up on a proposal made in 1977 at a LIBER (Ligue des Bibliothèques Européenes de Recherche) meeting in Leiden. It was agreed at that meeting that LIBER should try to publish national indexes for academic books. It was suggested that indexes be produced from four countries which together produce the principal part of European publishing output: Great Britain, France, Germany, and the Netherlands. It was also agreed that indexes conform to a standard defined by LIBER which included the use of the
UNESCO classification for subject headings and total number of publications per subject heading. Although Great Britain continued to produce its Academic Book Price Index (Centre for Library and Information Management), no other country had produced one by 1986 . Therefore, the Lynden study may assist in the renewal of the earlier effort by identifying the organizations which can produce price data and the individuals who have both the expertise and interest in the production of such indexes. It is clear that any future effort will require cooperation among vendors, librarians, and book trade association officials.

Lynden's research was made possible through the first annual grant from the Martinus Nijhoff Company, The Hague, The Netherlands, in a program advertised by ACRL's Western European Specialists Section. Funds will be given annually to encourage the study of some aspect of the acquisition, organization, or use of library materials from or relating to Western Europe.-WESS Newsletter.

\section{ACRL actions, January 1987}

\section{Highlights of the Midwinter meetings of the ACRL Board of Directors.}

$\mathbf{T}$ he Board of Directors of the Association of College and Research Libraries met twice during the ALA Midwinter Meeting in Chicago, Illinois: on Sunday, January 18, 1987, and Tuesday, January $20,1987$.

\section{ALA Divisions}

The Board made a recommendation to the ALA Committee on Program Evaluation and Support (COPES) that it include in the proposed Policies of the American Library Association in Relation to its Divisions a policy permitting divisions to earn interest. To be eligible to participate in the interest- generating program, a division would have to show at the beginning of two consecutive years a fund balance equal to at least $50 \%$ of the previous year's expenses. COPES will be examining the proposed policy further and will submit a final draft to ALA Council at the Midwinter Meeting 1988.

The Board also recommended to COPES that charges to divisions for new services be established only after mutual discussion and agreement between ALA and its divisions; and that a committee of division officers meet with representatives of COPES specifically to discuss proposed charges for Order/Billing and Subscription Services. 